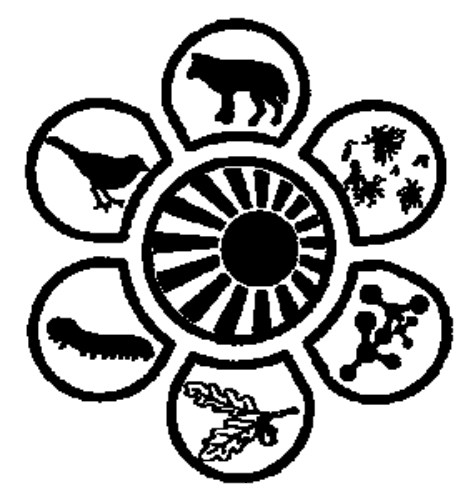

Вісник Дніпропетровського університету. Біологія, екологія.

Vìsnik Dnìpropetrovs'kogo unìversitetu. Serîa Bìologîâ, ekologiâ

Visnyk of Dnipropetrovsk University. Biology, ecology.

Vìsn. Dnìpropetr. Unìv. Ser. Bìol. Ekol. 2016. 24(2), 451-458.

doi:10.15421/011661

ISSN 2310-0842 print

ISSN 2312-301X online

www.ecology.dp.ua

UDC 598.293.1:591.5

\title{
Spatial patterns of habitat distribution of Corvidae (the case of urban-rural gradient)
}

\author{
A.A. Zimaroyeva ${ }^{1}$, A.V. Matsyura ${ }^{2}$, K. Jankowski ${ }^{3}$

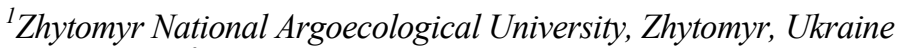 \\ ${ }^{2}$ Altai State University, Barnaul, Russia \\ ${ }^{3}$ Siedlce University of Natural Sciences and Humanities, Siedlce, Poland
}

The spatial distribution and abundance of Corvidae species in Zhytomyr region was studied in terms of the urban-rural gradient. We selected Rook (Corvus frugilegus L.), Eurasian Jackdaw (C. monedula L.), Hooded Crow (C. cornix L.), Common Raven (C. corax L.), Eurasian Magpie (Pica pica L.) and Eurasian Jay (Garrulus glandarius L.) for our observations during 2009-2012. Some 38 survey routes totaling more than $8000 \mathrm{~km}$ were surveyed in 21 settlements in Zhytomyr region. Among them 13 routes were in Zhytomyr city. The average density of Rooks was $55.9 \mathrm{birds} / \mathrm{km}^{2}$. We found a strong correlation between Rook density and rural-urban gradient and observed that the numbers of wintering Rooks in cities significantly increased due to the influx from villages. The peak number of Rooks in villages was registered in the breeding and post-breeding seasons while in the cities it was high in winter and during the spring migration. The average density of Eurasian Magpies in the study area was $8.7 \mathrm{birds} / \mathrm{km}^{2}$ and we registered weak correlation with the urban-rural gradient. Their maximum density in urban habitats was in the winter period whereas the highest density in rural habitats was fixed in the summer months. The density of Magpies varied insignificantly within a narrow range during the three years of research, which suggests the species has successfully adjusted to the transformed landscapes. Average density of Hooded Crows in towns was 6.6 birds $/ \mathrm{km}^{2}$. The linear relationship between the urban-rural gradient and the density of this species was rather weak. In the breeding period, the birds' density was considerably higher in urban habitats. We also registered that the average density of Hooded Crows changed insignificantly but gradually increased during the study period. The average density of Eurasian Jackdaws was $9.7 \mathrm{birds} / \mathrm{km}^{2}$ and had high annual dynamics. It also changed significantly during the three years of research. The average density of Eurasian Jays was $2.4 \mathrm{birds} / \mathrm{km}^{2}$ and varied significantly in different settlements, although the fluctuation range was small $\left(0.1-9.3 \mathrm{birds} / \mathrm{km}^{2}\right)$. We registered an expansion in the breeding distribution of Eurasian Jays in recent years i.e. the birds began to nest in old urban neighborhoods and small central parks of large cities. However, the number of birds naturally decreased along the gradient of landscape transformation. The impact of urban-rural gradient on Eurasian Jay density was significant but the correlation was weak and negative. The density of this species was highest in small villages $\left(4.9\right.$ birds $\left./ \mathrm{km}^{2}\right)$ and the lowest in medium-sized cities $\left(1.5 \mathrm{birds} / \mathrm{km}^{2}\right)$. The seasonal density of Jays varied significantly and the greatest value was registered in the post-breeding period. In urban areas the birds' density was much higher in winter compared to the nesting period, and in villages we observed the reverse situation. The number of Eurasian Jays remained almost stable in all the settlements during the study period indicating the stability of the local populations. The average density of the Common Raven was $1.3 \mathrm{birds} / \mathrm{km}^{2}$ and the highest density was registered in small villages $\left(2.2\right.$ birds $\left./ \mathrm{km}^{2}\right)$, the lowest - in the townships (small urban type settlements) $\left(0.6 \mathrm{birds} / \mathrm{km}^{2}\right)$. The urban-rural gradient significantly affected the spatial distribution of Common Ravens, but we cannot claim an increase or decrease in their numbers along the gradient of urbanization, since the value of this indicator also depended on habitat conditions in each specific settlement. The spatial distribution of Common Ravens varied seasonally and the highest density was typical in winter due to food migrations towards human settlements.

Keywords: urban habitats; spatial distribution; abundance; Ukraine

Житомирський національний агротехнологічний університет, вул. Старий бульвар, 7, Житомир, 10008, Украӥна Zhytomyr National Argoecological University, Stary Boulevard, 7, Zhytomyr, 10008, Ukraine

Алтайський державний університет, пр. Ленина, 61, Барнаул, 656049, Росія

Altai State University, Lenin Ave., 61, Barnaul, 656049, Russia

Природнично-гуманістичний університет в Седльще, вул. Конарського, 2, Седльие, 08-110, Польща Siedlce University of Natural Sciences and Humanities, ul. Konarskiego, 2, Siedlce, 08-110, Poland Tel.: +38-098-799-55-13.E-mail: anastasia_zima@yandex.ru, amatsyura@gmail.com,kazjankowski@gmail.com 


\title{
Особливості просторового та біотопічного розподілу воронових птахів (вплив градіснта урбанізації)
}

\author{
А.А. Зимароєва ${ }^{1}$ О.В. Мацюра ${ }^{2}$ К. Янковський ${ }^{3}$ \\ ${ }^{1}$ Житомирський національний агротехнологічний університет, Житомир, Украӥна \\ ${ }^{2}$ Алтайський державний університет, Барнаул, Росія \\ ${ }^{3}$ Природнично-гуманістичний університет в Седльце, Седльце, Польщฺа
}

\begin{abstract}
Протягом 2009-2012 рр. досліджено просторовий розподіл воронових птахів у Житомирській області відповідно градієнту антропогенного навантаження та сезонів року. У Житомирській області зустрічається шість видів воронових птахів: сіра ворона, ворон, грак, галка, сойка, сорока. Середня щільність граків у перший рік досліджень (2009-2010рр.) становила 50,1 ос./км², у другий (2010-2011рр.) - 58,3 ос./км², у третій (2011-2012рp.) - 59,4ос./км². Зростанню чисельності та подальшій урбанізації сірої ворони, на нашу думку, сприяє велика кількість кормів антропогенного походження, у вигляді харчових і господарських відходів, що дозволяє птахам пережити суворі погодні умови. Інтенсивне зростання чисельності сірої ворони стримує конкуренція з боку грака. За період досліджень помітно змінилася щільність галки в містах. Це свідчить про зростання чисельності міських популяцій i доводить, що у Житомирській області галка - типовий синурбаніст. Сойка активно заселяє всі типи населених пунктів області, а також триває ії входження до найбільше перетворених людиною ландшафтів (великі міста), де ії чисельність із року в рік зростаєспостерігається активна синантропізація виду. Середня щільність крука за три роки досліджень суттєво не змінилася, хоча спостерігалось ії незначне підвищення з 1,2 ос./км² у 2009-2010 pp. до 1,5 ос./км² у 2011-2012 роках.
\end{abstract}

Ключові слова: просторовий розподіл; чисельність; Житомир; Україна

\section{Introduction}

Birds are an integral part of many ecosystems and quickly respond to the impact of various environmental factors. Birds are a rather ecologically flexible group of vertebrates, which can acquire new adaptations and extend their distribution into human settlements under the influence of anthropogenic factors (Clergeau et al., 1998; Luniak, 2004; Blair and Johnson, 2008; Jokimäki et al., 2009). We have distinguished five categories reflecting the successive stages of bird synanthropization (synurbization): seasonal synanthropic - birds visiting population centers, but only reproducing outside human settlements; passive synanthropic - birds, that nest in settlement habitats which are close to nature; optional synurbanistic - birds that breed in settlements; developed synurbanistic - birds, more than a quarter of whose population inhabit urbanized areas and are characterized by certain biological differences from birds inhabiting natural habitats; extreme (full) synurbanistic - birds, the majority of whose population reproduces exclusively in human settlements (Chace and Walsh, 2006; Marzluff and Rodewald, 2008; Møller et al., 2012; Leveau, 2013). Nowadays, Corvidae prefer man-made landscapes and are well adapted to live in both urban and rural habitats due to their high ecological adaptability (Tratalos et al., 2007; Strohbach et al., 2009; Ramalho and Hobbs, 2012). These birds can occupy ecological niches with significant temperature fluctuations, and their generally high metabolism contributes to their omnivorous character and environmental flexibility (Blair and Johnson, 2008; Luck and Smallbone, 2010; Jokimäki and Kaisanlahti-Jokimäki, 2012).

Therefore, many corvids exhibit typical synanthropic features: they actively explore man-made landscapes, are numerous in towns, and therefore cause problems for municipal and sanitary-epidemiological services in places of high concentrations (Conole and Kirkpatrick, 2011; Kendall et al., 2013; Tryjanowski et al., 2015a). Currently, there is a large number of papers relating to the ecology of Corvidae in anthropogenic landscapes (McGowan, 2001; Goławski and Dombrowski, 2011; Laband et al., 2013; Tryjanowski et al.,
2013; Tryjanowski et al., 2015b). This high level of interest in the study of Corvidae is associated not only with their large taxonomic and ecological diversity, but also with the challenges posed by their behavior and their practical importance (Luniak, 2004; Marzluff and Rodewald, 2008; Radford and James, 2013).

Research related to the study of corvids in the man-made and natural landscapes of Ukraine remains fragmented and has received hardly any detailed study. A few papers provide data concerning the size or density of certain species in different regions of Ukraine (Poluda and Tsukanova, 2012; Matsyura et al., 2015; Matsyura and Zimaroyeva, 2016). The impact of the rural-urban gradient on corvids in Ukraine has been almost unexplored. The aim of our research was to determine the degree of influence of the rural-urban gradient on the seasonal abundance and density of corvids in various settlements of Zhytomyr region.

\section{Materials and methods}

All bird surveys were conducted within Zhytomyr region, which is located in northern Ukraine (Fig. 1). The administrative center of the oblast is the city of Zhytomyr. Population is 268,903 (2013 est.). The total area of Zhytomyr Oblast is $29,832 \mathrm{~km}^{2}$. Coordinates: $50.65^{\circ} \mathrm{N} 28.52^{\circ} \mathrm{E}$.

We have allocated 5 habitat types within the city. Zhytomyr and the suburban "green zone" (mixed forests, forest parks and ponds). The habitats within the urban areas are: old buildings (2-5 floors), multi-storey buildings (914 floors), individual buildings, habitats with artificial green spaces (parks, squares, boulevards) built into the architecture of the city, industrial landscapes. We took into consideration the percentage of various buildings and their distribution, degree of habitat gardening and human pressure.

At the local level (municipal) the urban-rural gradient increases toward suburban green areas (forests, riverine habitats, fields-buffer zones, which are closely associated with the city's economic activity and the flow of tourists), industrial buildings (industrial landscape), cottages, city parks, squares, boulevards, gardens, typical high rise buildings. 


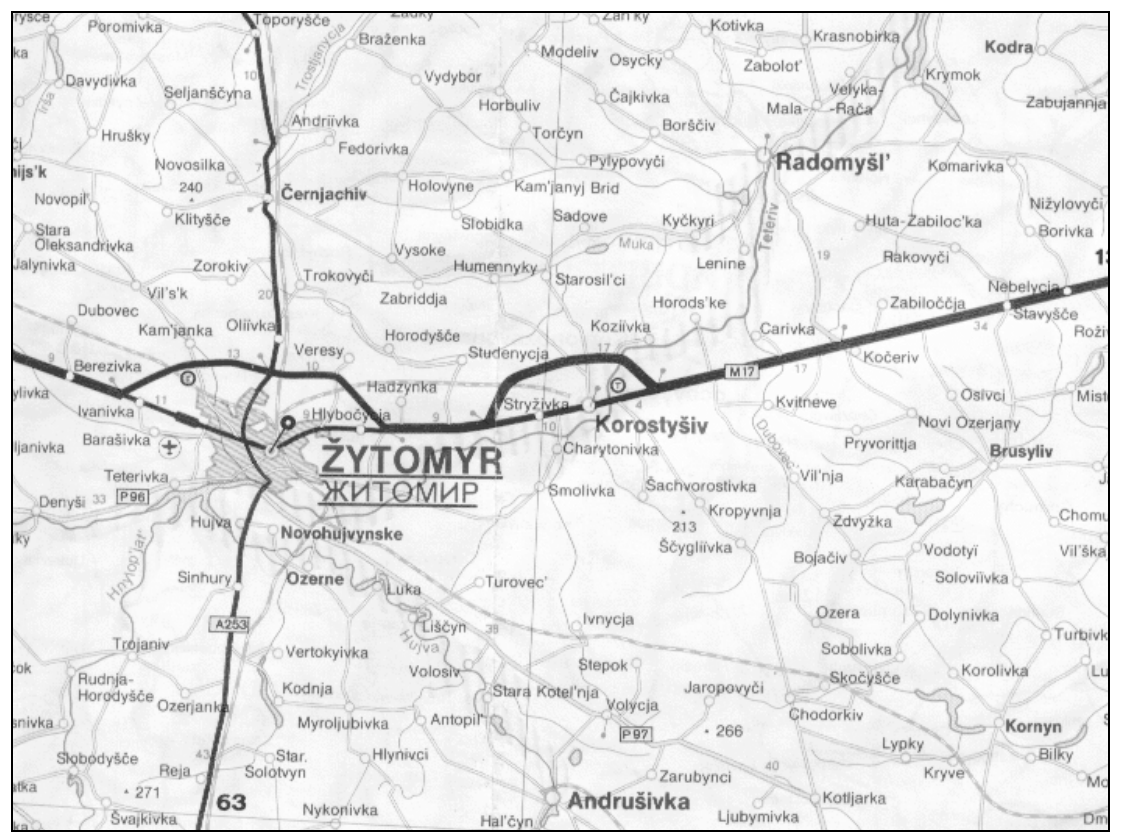

Fig. 1. Map covering the area around the city of Zhytomyr

The urban-rural gradient was scaled: 1 - small villages, 2 - middle-sized villages, 3 - large villages, 4 - townships (small urban type settlements), 5-small towns, 6-mediumsized towns, 7 - large cities.

The research objects were Corvus frugilegus L., C. monedula L., C. cornix L., C. corax L., Pica pica L., Garrulus glandarius L. We performed our survey on 38 routes ( 13 were in the city of Zhytomyr) and 21 were in villages (the length of our routes totalled more than $8.000 \mathrm{~km}$ ).

The heterogeneity of the urban habitats and lack of adequate field techniques for bird counts in urban areas made it impossible to use a single method for determining the numbers of birds. Therefore, we took a differentiated approach. We used the transect method with variable-width strips in the conditions with different distances between buildings. For the birds in flight, the population density was calculated by Yapp (Bibby et al., 1992):

$$
A=\frac{\mathrm{s}}{2 \pi \cdot \sqrt{w_{1}^{2}+w_{2}^{2}}}
$$

where $N$ - number of birds $/ \mathrm{km}^{2}, n$ - number of birds in flight, $R$ - radial detection range of individuals (groups of individuals, $\mathrm{km}$ ), $t$ - duration of observation (hours), $v_{l}-$ the speed of a bird (for Hooded Crow $-50 \mathrm{~km} / \mathrm{h}$, for others $30 \mathrm{~km} / \mathrm{h}), v_{2}$ - the speed of the observer $(\mathrm{km} / \mathrm{h})$.

The transect width was averaged and it was: for old (35 storey) buildings $-60 \mathrm{~m}$, within cottage areas $-100 \mathrm{~m}$, for high rise buildings (9-14-storey) $-80 \mathrm{~m}$, in the industrial zone $-200 \mathrm{~m}$, in parks, squares and boulevards $-300 \mathrm{~m}$.

We used Finnish transect methods in city parks and forest parks. For birds in flight, the density calculation was performed as follows (Ravkin and Chelintsev, 1990):

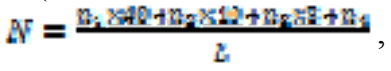

where $t$ - the time of observation (hours), $v$ - the speed of a bird (for Hooded Crow $-50 \mathrm{~km} / \mathrm{h}$, for others $-30 \mathrm{~km} / \mathrm{h}$ ).

We used seasonal differentiation of birds' life cycle as follows: winter (November, 1 - February, 15), pre-breeding (February, 16 - March, 30), nesting (April, 1 - June, 30), post-breeding period (1 July - 31 August) and autumn migration period (September, 1 - October, 30).

Statistical data processing was carried in Statistica 11.0 (Statsoft Inc., USA). We used the Kolmogorov-Smirnov test to determine the normal distribution. The level of significance was $5 \%$, the difference between the averages was considered significant when the probability was $\mathrm{P}<0.05$. We made the assessment of linear linkage by correlation analysis with the Pearson coefficient. To establish reliable statistical differences between samples we used the t-Student test for independent samples and Fisher's criterion. If distribution was defined as non-normal, we used nonparametric tests with the Mann-Whitney criterion. Multiple regression was applied for the factor analysis.

\section{Results}

Some birds spend almost all their life cycle within the settlement areas, while species demonstrated definite fluctuations and distribution patterns in terms of their density, which were subject to habitat changes. These changes also reflected annual and seasonal factors which we describe below.

We observed that the Corvidae distribution patterns per habitat and seasons are not even, there were some density peaks which varied in a species-specific way (Fig. 2). Moreover, these patterns reflect adaptability of species, their tolerance to humans and habitat availability and seasonal preference.

The density and distribution of Rooks. The average density of the Rook was 55.9 birds $/ \mathrm{km}^{2}$ ( $\mathrm{n}=2,924$; SD = 94.2) and this varied from $0.4 \mathrm{birds} / \mathrm{km}^{2}$ in the small village of Staraya Aleksandrovka to $79.0 \mathrm{birds} / \mathrm{km}^{2}$ in the city of Zhytomyr. We revealed that the population density of Rooks was not normally distributed (Kolmogorov-Smirnov test; $\mathrm{d}=$ 0.28 ; $\mathrm{P}<0.01)$. We revealed a positive relation between Rook density and the rural-urban gradient $(\mathrm{P}<0.05)$, which indicates high synanthropization of Rooks in Zhytomyr region. Rook density varies considerably in different types of settlements $(\mathrm{F}=13.4 ; \mathrm{P}<0.001)$ and did not change linearly 
towards the gradient of anthropogenic loading. The highest density of Rooks in the settlements was registered in winter in urban areas, especially in the city of Zhytomyr. Thus, the average winter density of Rooks in Zhytomyr for 2009-2012 was $182.4 \mathrm{birds} / \mathrm{km}^{2}$.

It is assumed (Matsyura et al., 2015) that the increase in the number of Rooks in urban areas of Ukraine is caused by the migration of Rook populations from Northern Europe.
This also supported by the large number of Rooks which do not leave for the wintering territories after the breeding season and this is true not only for the adults but also for young birds (Poluda and Tsukanova, 2012). We also found that the number of Rooks that overwinter in cities significantly increased due to the influx from suburban villages, i.e. the numbers of rural Rooks fell in winter whereas the abundance of urban Rooks increased.

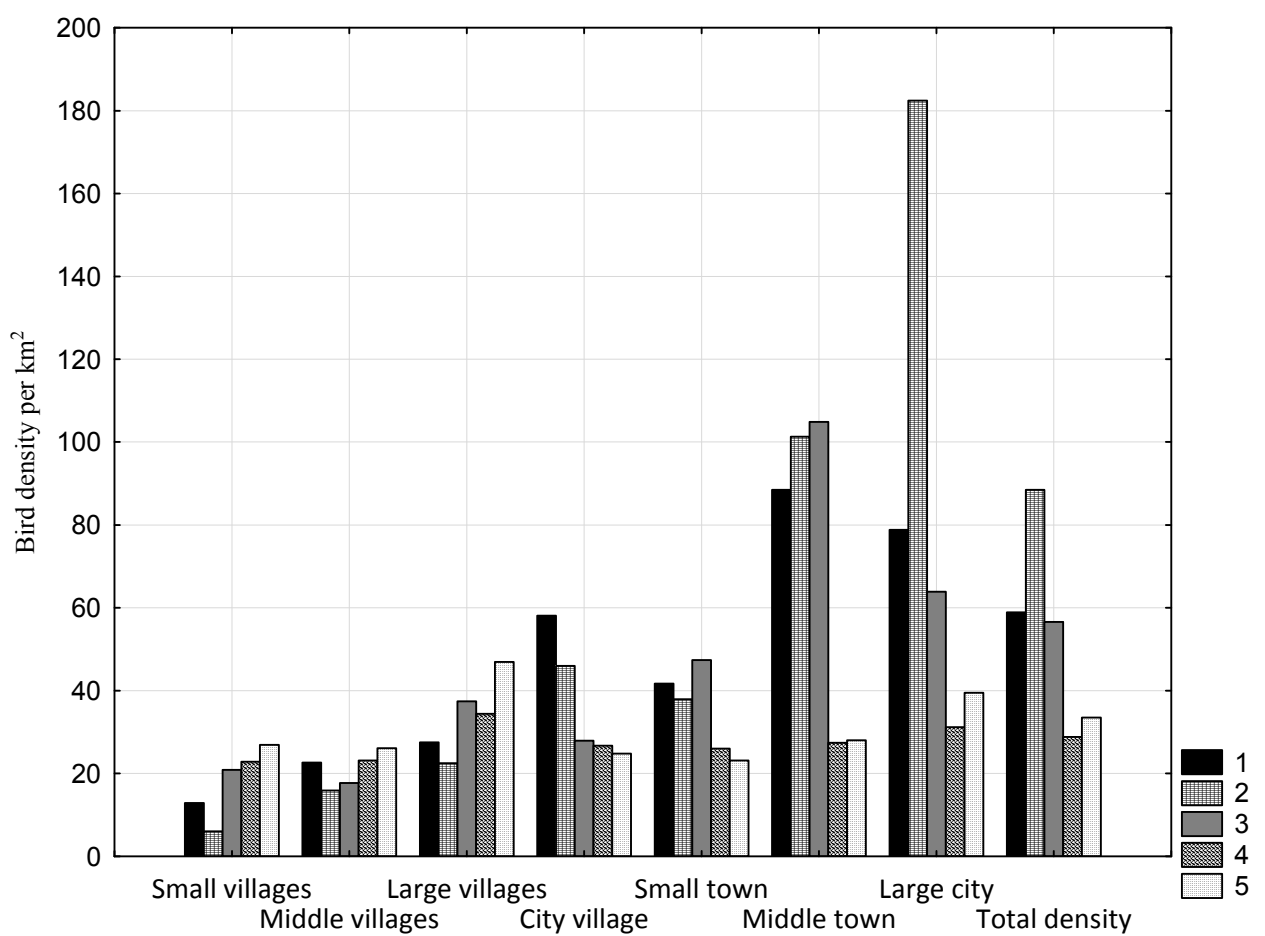

Fig. 2. Corvid density in various habitats per season:

they are presented on OX axis: 1 - winter, 2 - pre-breeding, 3 - nesting, 4 - post-breeding and 5 - autumn migration period

We concluded that Corvidae abundance is subject to different fluctuations in different type of settlements. Thus, the peak number of rural Rooks was reached in the nesting and post-breeding periods, whereas the peak for urban Rooks came in winter and during spring migration. This may be associated with migrations of corvids since in winter they moved from villages to cities, where there are sufficient food resources and the air temperatures are higher. During the prebreeding period the birds migrate back to the villages, where most of them nest. In summer, the numbers of Rooks in urban areas drops - birds fly away from the cities and feed on the fields and gardens in suburban villages, where their density naturally increases.

The high density of Rooks during spring and autumn migrations is related, obviously, to the presence of Rooks which migrate from other regions outside the study area. Mass spring migration of Rooks through Zhytomyr region takes place from the third week of February - the first week of March. The temporal patterns of this passage are closely correlated to weather conditions: during the prolonged cold winter of 2012 we observed the start of passage only in early March, while in 2009 the first wave of spring migration began at the end of the first decade of February. In autumn the Rooks start their migration in late September - early October and complete it in the first week of November. In October, Rook migration activity is quite noticeable: we able to record thousands of flocking Rooks, which often roost at night in human settlements. The first wintering flocks appear in human settlements in the first half of October. Their number increases rapidly in late October - first week of November and continues to grow throughout the whole winter.

Rooks are the absolute dominant of winter corvid populations at landfill sites in all the settlements we observed. It should be noted that while the Rook dominates both in rural and urban landfills, the number of Rooks in urban landfills are much greater than in villages. Sometimes we surveyed about 5,000 Rooks in a cold and snowy winter in a solid waste landfill site in Zhytomyr. Factor analysis was performed for Rook density in order to estimate the character of dependency of bird density upon season, year number and habitat (Table 1).

We can consider that season and habitat are the principal factor of density fluctuation in settlement areas, while annual changes are not so pronounced.

Patterns of spatial distribution of the European Magpie. The average density of the European Magpie was 8.7 birds $/ \mathrm{km}^{2}(\mathrm{n}=2,919 ; \mathrm{SD}=11.2)$ and had an abnormal distribution (Kolmogorov-Smirnov criteria, Lilliefors test, $\mathrm{P}<0.01$ ). The distribution and abundance of Magpies in various habitats was associated primarily with the presence of thickets of bushes, interspersed with open spaces, i.e., the density of Magpies was significantly affected by the natural and spatial conditions of each specific locality $(\mathrm{F}=9.3 ; \mathrm{P}<$ 0.001). Magpie density was correlated with anthropogenic 
loading but this link was rather weak (correlation coefficient $0.18, \mathrm{~F}=20.1 ; \mathrm{P}<0.001)$.

Overall, the density of Magpies increases from less to more human-transformed landscapes and the highest average density was registered in Zhytomyr $\left(10.2 \mathrm{birds} / \mathrm{km}^{2}\right)$. Comparison of mean density values of Magpies in settlements with different anthropogenic loading made it possible to identify the following trends: the density of Magpies in small villages is significantly different from all other types of set- tlements except for secondary villages $(\mathrm{P}=0.66)$; the density of birds in large villages insignificantly differs from density in townships $(\mathrm{P}=0.21)$, towns $(\mathrm{P}=0.84)$, medium-sized cities $(\mathrm{P}=0.88)$ and Zhytomyr $(\mathrm{P}=0.38)$. The density of Magpies in townships significantly different from those in small, medium-sized towns and the city of Zhytomyr. The density of Magpies in urban areas significantly differs only from density of birds in villages with a population of less than 1,000 people $(\mathrm{P}<0.05)$.

Results of factor analysis for Rook density in settlement areas

$\left(R=0.402, R^{2}=0.161\right.$, Adjusted $\left.R^{2}=0.159, F_{3,1162}=74.544, P<0.002\right)$

\begin{tabular}{|c|c|c|c|}
\hline Parameter & Season & Year & Habitat \\
\hline P-value & 0.000 & 0.028 & 0.000 \\
\hline Standardized coefficient & -0.303 & 0.059 & 0.269 \\
\hline Unstandardized coefficient & -28.944 & 9.322 & 21.941 \\
\hline Std. Error & 2.573 & 4.232 & 2.193 \\
\hline $\mathrm{t}$ & -11.248 & 2.202 & 10.007 \\
\hline
\end{tabular}

The analysis of the annual density of Magpies revealed the non-significant effect of period on the number of birds in the city of Zhytomyr ( $\mathrm{F}=1.87$; $\mathrm{P}>0.05)$ : the average number of Magpies remained unchangeable throughout the seasons. However, we found some differences in the dynamics of Magpie numbers in different types of settlements. Thus, the maximum density in cities was in winter, and in the villages it was maximal in summer months. This can be explained by the fact that a small number of winter birds entered the city from surrounding villages in search of food, especially on cold days, and that with the onset of spring the birds return to their nesting places.
The relatively high number of Magpies in rural areas in summer is related, on the one hand, to the increasing number of local populations due to the appearance of young birds, on the other hand, to feeding flights of Magpies from the outskirts of the city into country homestead areas and gardens which that are located outside the city. Magpie density varied significantly $(\mathrm{F}=0.58 ; \mathrm{P}>0.05)$ in the research period 2009-2012, the highest was registered in 2010 (9.0 birds $/ \mathrm{km}^{2}$ ). In 2009, Magpie density was $8.5 \mathrm{birds} / \mathrm{km}^{2}$, and in $2012-8.7 \mathrm{birds} / \mathrm{km}^{2}$. Thus, Magpie density varies in a very narrow range, remaining relatively stable, which indicates a high level of adaptation to the urban environment.

Results of factor analysis for European Magpie density in settlement areas $\left(R=0.081 ; R^{2}=0.007 ;\right.$ Adjusted $\left.R^{2}=0.004 ; F_{3,1162}=2.542 ; P<0.05\right)$

\begin{tabular}{|l|r|r|r|}
\hline \multicolumn{1}{|c|}{ Parameter } & Season & Year & Habitat \\
\hline P-value & 0.166 & 0.510 & 0.019 \\
\hline Standardized coefficient & -0.041 & 0.019 & -0.069 \\
\hline Unstandardized coefficient & 0.402 & 0.314 & -0.579 \\
\hline Std. Error & 0.289 & 0.476 & 0.247 \\
\hline $\mathrm{t}$ & 1.387 & 0.659 & -2.351 \\
\hline
\end{tabular}

We can consider that habitat is the only significant factor in Magpie density fluctuation in settlement areas, while other factors are not significant.

Patterns of spatial distribution of the Hooded Crow. The gradient of anthropogenic loading significantly affects the density of Hooded Crows $(\mathrm{F}=29.2 ; \mathrm{P}<0.001)$. The average urban density was $6.6 \mathrm{birds} / \mathrm{km}^{2}$. The linear relationship between anthropogenic pressure gradient and the density of Hooded Crows was rather weak (correlation coefficient $0.23 ; \mathrm{P}<0.05)$.

Despite the significant effect of urban-rural gradient, only in small villages and large cities did the density of this species significantly differ from those in all other settlements $(\mathrm{P}<$ $0.05)$; the density of birds in medium, large villages and towns varied slightly among themselves $(\mathrm{P}>0.05)$; the difference in the density of Hooded Crows in small and medium-sized cities was unreliable $(\mathrm{P}>0.05)$.

Total abundance of crows varied considerably in the settlement areas $(\mathrm{F}=9.9 ; \mathrm{P}<0.001)$ and normally it is not sub- ject to linear changes along the rural-urban gradient. Hooded Crows were registered in all the towns and cities in the region, the highest was noted in Zhytomyr $-9.2 \mathrm{birds} / \mathrm{km}^{2}$. The density also varied significantly in relation to the season $(\mathrm{F}=4.8 ; \mathrm{P}<0.01)$. Winter distribution of crows was determined by the degree of economic development of the territory, thus birds are always located near human habitation along highways and railways, and in rural areas they concentrated around farms and livestock. In early spring birds begin to move towards their nesting areas, however, their number in urban areas, compared to the winter period, decreases. We established that urban populations of Hooded Crows had low densities during the breeding season, while in the villages, on the contrary, the density of crows was greater at that time than in autumn and winter, due to the distribution of birds in their breeding areas and the start of the reproductive cycle.

The crow populations increase in all types of humantransformed landscapes in first weeks of the post-breeding period, which is associated primarily with the dispersal of 
young birds. Later (in July and August), the number of crows in urban areas decreased, but their density increased on the outskirts of cities, suburban areas and surrounding villages.

The average density of the Hooded Crow did not change significantly $(\mathrm{P}>0.05)$, although it gradually grew over the years: in the first year of study (September 2009 - August 2010 ) it was 6.1 birds $/ \mathrm{km}^{2}$, in the second (September 2010 August 2011) - 6.7 birds $/ \mathrm{km}^{2}$, and in third (September 2011 August 2012) -7.0 birds $/ \mathrm{km}^{2}$. We concluded that season and habitat are the principal factor of density fluctuation in settlement areas, while annual changes are not significant.

The number and distribution of Eurasian Jackdaws. The average density was registered as $9.7 \pm 0.4 \mathrm{birds} / \mathrm{km}^{2}$ $(\mathrm{n}=2,921 ; \mathrm{SD}=21.9)$ and cannot be considered as normal (Kolmogorov-Smirnov test, Lilliefors test, $\mathrm{P}<0.01$ ). We also found that urban-rural gradient significantly affected the density of Jackdaws ( $\mathrm{F}=28.4 ; \mathrm{P}<0.001)$.

In general, the population density of Jackdaws increased in the transition to more urban areas; with an exception to the general trend in middle sized villages, where the density was abnormally high. This was caused by the influence of specific climatic conditions in the studied settlements and the large population of nesting Jackdaws.

For Jackdaws we observed a noticeable seasonal dynamic: the highest density of urban birds was in winter, which can be explained by the large amount of migrant birds. The maximum number (268 birds $/ \mathrm{km}^{2}$ ) was registered in the city of Zhytomyr in February 2012 (a period of extremely low temperatures) in the central districts. The seasonal factor significantly affected the population density $(\mathrm{F}=18.7 ; \mathrm{P}<$ 0.001 ), although there are some distinctions in seasonal dynamics of density in different settlements. Thus, the peak number of birds in cities and towns was in the winter months, and in the villages - during the breeding and postbreeding periods. Jackdaws return to their nesting sites in spring and in rural areas the density of birds in the nesting period is greater compared to the winter months, and in the cities the reverse applies.

In the post-breeding period Jackdaw density increases in villages and cities due to the influx of young birds. Autumn migration of this species, along with the Rook, begins in the first week of October and it ends in the beginning of November. In winter the urban Jackdaws formed mixed flocks with Rooks, in which they made mutual daily and overnight movements in search of food.

Density of birds changed significantly within the study period $(\mathrm{F}=4.8 ; \mathrm{P}<0.001)$. In 2010 the average density was 8.2 birds $/ \mathrm{km}^{2}$, in $2011-9.8$ birds $/ \mathrm{km}^{2}$, and in $2012-$ 11.3 birds $/ \mathrm{km}^{2}$.

Results of factor analysis for Hooded Crow density in settlement areas $\left(R=0.184 ; R^{2}=0.034 ;\right.$ Adjusted $\left.R^{2}=0.031 ; F_{3,1159}=13.464 ; P<0.001\right)$

\begin{tabular}{|l|r|r|r|}
\hline \multicolumn{1}{|c|}{ Parameter } & Season & Year & Habitat \\
\hline P-value & 0.000 & 0.113 & 0.000 \\
\hline Standardized coefficient & -0.117 & 0.046 & -0.127 \\
\hline Unstandardized coefficient & -1.184 & 0.763 & -1.098 \\
\hline Std. Error & 0.293 & 0.481 & 0.249 \\
\hline $\mathrm{t}$ & -4.049 & 1.586 & -4.406 \\
\hline
\end{tabular}

Results of factor analysis for Eurasian Jackdaw density in settlement areas $\left(R=0.208 ; R^{2}=0.044 ;\right.$ Adjusted $\left.R^{2}=0.041 ; F_{3,1161}=17.588 ; P<0.001\right)$

\begin{tabular}{|l|c|r|r|}
\hline \multicolumn{1}{|c|}{ Parameter } & Season & Year & Habitat \\
\hline P-value & 0.286 & 0.049 & 0.000 \\
\hline Standardized coefficient, & 0.031 & 0.057 & -0.199 \\
\hline Unstandardized coefficient & 0.142 & 0.219 & 0.114 \\
\hline Std. Error & 0.133 & 0.219 & 0.114 \\
\hline $\mathrm{t}$ & 1.068 & 1.975 & -6.929 \\
\hline
\end{tabular}

Here we observed the significant influence of annual fluctuations and habitats on Jackdaw density, the seasonal factor is not significant.

Main patterns of Eurasian Jay habitat distribution. Average density of Eurasian Jays was $2.4 \pm 0.1 \mathrm{birds} / \mathrm{km}^{2}$ $(\mathrm{n}=2,922 ; \mathrm{SD}=5.3)$ and had a normal distribution (criteria of Kolmogorov-Smirnov, Lilliefors test, $\mathrm{P}<0.01$ ). Jay density varied significantly in different locations $(\mathrm{F}=15.9 ; \mathrm{P}<$ 0.001 ) from 0.1 to $9.3 \mathrm{birds} / \mathrm{km}^{2}$. The percentage of Jays among corvids as a whole varied from 0.2 to 22.3 . We observed an expansion of nesting Jays in habitats of old green urban areas and small parks in the city center, however, the number of this species naturally decreases along the gradient of human transformation of the landscape.

The impact of anthropogenic pressure on the Eurasian Jay is significant $(\mathrm{F}=17.1 ; \mathrm{P}<0.001)$, the highest density was registered in small villages $\left(4.9 \mathrm{birds} / \mathrm{km}^{2}\right)$ and the lowest - in medium-sized towns ( 1.5 birds $\left./ \mathrm{km}^{2}\right)$. There is a weak negative correlation between rural-urban gradient and Jay density $(\mathrm{r}=-0.16 ; \mathrm{P}<0.05)$.

Density of Eurasian Jays significantly changed with season $(\mathrm{F}=3.5 ; \mathrm{P}<0.001)$ : the greatest density was registered in the post-breeding season (due to the dispersal of young birds). We have also identified certain characteristics in the seasonal dynamics of Jays depending on settlement type. In urban areas the density of Jays was higher in winter compared to the nesting period, and in the villages we observed the reverse situation. We believe this species is rather nomadic within Zhytomyr region and makes short-distance food flights, especially in winter, when natural habitats have depleted food resources, and when there is plenty of food in areas of human settlement. 
The number of Jays in all the regional settlements remained almost unchanged within the study period, indicating a definite stability of local populations, although we observed a slight tendency to increase their number: in 2010 the density was $2.2 \mathrm{birds} / \mathrm{km}^{2}$, in $2011-2.3 \mathrm{birds} / \mathrm{km}^{2}$, and in $2012-2.6$ birds $/ \mathrm{km}^{2}$. All the factors had a significant influence on the birds' density, the principal are season and habitat, the former had a negative effect.

The numbers and distribution of the Common Raven. The average density of the Common Raven was $1.3 \pm$ 0.1 birds $/ \mathrm{km}^{2}(\mathrm{n}=2,682 ; \mathrm{SD}=3.7)$ with non-normal distri- bution (Kolmogorov-Smirnov criterion, Lilliefors test, $\mathrm{P}<$ 0.01 ). This species made up $0-33.7 \%$ of the total number of Corvidae in the settlement areas. The highest density of Ravens was registered in small villages $-2.2 \mathrm{birds} / \mathrm{km}^{2}$, and the smallest - in townships -0.6 birds $/ \mathrm{km}^{2}$.

Although the gradient significantly affected the spatial distribution of the Common Raven $(\mathrm{F}=6.3 ; \mathrm{P}<0.001)$, we cannot consider that Raven density increases or decreases in relation to degree of urbanization, because the value of this indicator also depends strongly on specific habitat conditions of each settlement area.

Results of factor analysis for Eurasian Jay density in settlement areas

$$
\left(R=0.347 ; R^{2}=0.121 ; \text { Adjusted } R^{2}=0.118 ; F_{3,1160}=52.854 ; P<0.001\right)
$$

\begin{tabular}{|l|r|r|r|}
\hline \multicolumn{1}{|c|}{ Parameter } & Season & Year & Habitat \\
\hline P-value & 0.000 & 0.001 & 0.000 \\
\hline Standardized coefficient, & -0.171 & 0.092 & 0.294 \\
\hline Unstandardized coefficient & -3.664 & 3.259 & 5.383 \\
\hline Std. Error & 0.592 & 0.973 & 0.504 \\
\hline$t$ & -6.189 & 3.351 & 10.675 \\
\hline
\end{tabular}

Results of factor analysis for Common Raven density in settlement areas $\left(R=0.423 ; R^{2}=0.179 ;\right.$ Adjusted $\left.R^{2}=0.177 ; F_{3,1163}=84.671 ; P<0.001\right)$

\begin{tabular}{|l|r|r|r|}
\hline \multicolumn{1}{|c|}{ Parameter } & Season & Year & Habitat \\
\hline P-value & 0.015 & 0.234 & 0.000 \\
\hline Standardized coefficient, & -0.065 & 0.032 & -0.414 \\
\hline Unstandardized coefficient & -0.234 & 0.191 & -1.295 \\
\hline Std. Error & 0.098 & 0.161 & 0.083 \\
\hline $\mathrm{t}$ & -2.441 & 1.192 & -15.573 \\
\hline
\end{tabular}

We can consider that season and habitat are the principal factors behind density fluctuation in settlement areas, while annual changes are not significant. Distribution of Ravens in the studied region had strong seasonal variation $(\mathrm{F}=8.4 ; \mathrm{P}<$ $0.001)$. Ravens were typical in all populated areas in winter, due to winter feeding movements into the urban areas. In spring birds returned to their breeding grounds and in summer they dispersed among natural habitats in search of available food. Autumn flocks of Ravens tended to move into populated areas again.

As reported by Møller et al. (2012), the contemporary avifauna of an urbanised area is a legacy of the species present in the former landscape, rather than solely being the product of invasion or colonisation. Since urban areas tend to substitute for forest-belts and Corvidae are rather woodlandadapted species (Conole and Kirkpatrick, 2011) we presume that corvids have a great potential to adapt to urban habitats.

For instance, in Berlin the abundance of Corvidae progressively increases from Common Raven to Jackdaw, Rook, Eurasian Jay, European Magpie and Hooded Crow (Otto and Witt, 2002). It is believed that Hooded Crows and Magpies are more successful in establishing themselves in urban environments compared to the other corvid species. However, we observed that patterns of abundance and distribution can differ between and within cities and along the urban-rural gradient. Moreover, we found that in our conditions the Rook is the most abundant corvid species.

\section{Conclusions}

We showed marked differences in distribution of Corvidae between urban and rural areas, the intensity of which varied upon season and habitat.

The numbers of birds were by far higher in the urban areas, confirming better habitat and food condition in the cities. Consequently, many more birds were noted in urban compared to rural areas in almost all habitats. The composition of bird communities was affected by species-specific habitat selectivity and tolerance towards humans. Although species richness was similar in both environments, community composition varied according to the type of habitat; for example, some species were primarily associated with food available in urban conditions and not in the rural areas.

These data contribute to the general conclusion that urban-rural gradient has large ecological impacts, affecting the numbers, distribution and behavior of Corvidae during their life cycle. However, we documented clear differences in distribution between urban and rural habitats and clear patterns in responses of birds to these differences. These patterns are likely to be directly linked to various avian adaptations and other drivers of successful urbanization, such as tolerance to humans, food selectivity. Populations of Corvidae are therefore subject to various pressures in response to changing urbanization gradients; however, their effects should be studied further. 
We have proved that the density of birds differs between urban and rural areas, and that preferences between these two types of environment exist. We cannot state that these preferences appear to be highly species-specific, but in urban and rural areas the birds are significantly affected by environmental variables, such as habitat, season, population fluctuation, and available food resources.

\section{References}

Andersen, L., Hoerschelmann, H., 1996. Siedlungsdichte, Reviergrosse und Bruterfolg von Rabenkrahen (Corvus corone L.) in der Grossstadlandschaft Hamburgs. Hamburg. Avifaun. Beitr. 28, 17.

Bibby, C.J., Burgess, N.D., Hill, D.A., 2002. Bird census techniques. Academic Press, London.

Blair, R.B, Johnson, E.M., 2008. Suburban habitats and their role for birds in the urban - rural habitat network: Points of local invasion and extinction? Landscape Ecol. 23, 1157-1169.

Chace, J.F, Walsh, J.J., 2006. Urban effects on native avifauna: A review. Landscape Urban Plan. 74, 46-69.

Ciach, M., 2012. The winter bird community of rural areas in the proximity of cities: low density and rapid decrease in diversity. Pol. J. Ecol. 60, 193-199.

Clergeau, P., Savard, J.P.L., Mennechez, G., Falardeau, G., 1998. Bird abundance and diversity along an urban-rural gradient: A comparative study between two cities on different continents. Condor 100, 413-425.

Conole, L., Kirkpatrick, J.B., 2011. Functional and spatial differentiation of urban bird assemblages at the landscape scale. Landscape Urban Plan. 100, 11-23.

Evans, K.L., Newson, S.E., Gaston, K.J., 2009. Habitat influences on urban avian assemblages. Ibis 151, 19-39.

Fuller, R.A., Irvine, K.N., Davies, Z.G., Armsworth, P.R., Gaston, K.J., 2012. Interactions between people and birds in urban landscapes. Stud. Avian Biol. 45, 249-266.

Goławski, A., Dombrowski, A., 2011. The effects of weather conditions on the numbers of wintering birds and the diversity of their assemblages in villages and crop fields in eastcentral Poland. Ital. J. Zool. 78, 364-369.

Hou, Y., Müller, F., Li, B., Kroll, F., 2015. Urban-rural gradients of ecosystem services and the linkages with socioeconomics. Landscape Online 39, 1-31.

Jokimäki, J., Kaisanlahti-Jokimäki, M.-L., 2012. Residential areas support overwintering possibilities of most bird species. Ann. Zool. Fenn. 49, 240-256.

Jokimäki, M.-L., Hakkarainen, H., Huhta, E., Inki., K, Suorsa, P., 2009. Urbanization and stability of a bird community in winter. Ecoscience 16, 502-507.

Kendall, W.L., Hines, J.E., Nichols, J.D., Grant, E.H., 2013. Relaxing the closure assumption in occupancy models: staggered arrival and departure times. Ecology 94(3), 607-610.

Laband, D.N., Lockaby, B.G., Zipperer, W.C., 2013. Urbanrural interfaces: Linking people and nature. American Society of Agronomy, Soil Science Society of America, Crop Science Society of America, Inc. Madison, USA.

Leveau, L.M., 2013. Bird traits in urban-rural gradients: How many functional groups are there? J. Ornithol. 154, 655-662.

Luck, G.W., Smallbone, L.T., 2010. Species diversity and urbanization: Patterns, drivers and implications. In: Gaston K.J. (ed.) Urban ecology. Cambridge University Press, Cambridge.

Luniak, M., 2004. Synurbization - adaptation of animal wildlife to urban development. Proceed. 4 Int. Urban Wildlife Symp. P. 50.
Mac Nally, R., 2000. Regression and model-building in conservation biology, biogeography and ecology: the distinction between and reconciliation of 'predictive' and 'explanatory' models. Biodivers. Conserv. 9, 655-671.

Marzluff, J.M., Rodewald, A.D., 2008. Conserving biodiversity in urbanizing areas: Nontraditional views from a bird's perspective. Cities and the Environment 1(2), article 6.

Matsyura, A., Jankowski, K., Zimaroeva, A., 2015. Escape behaviours of Corvidae in an urban ecosystem of Zhytomyr (Ukraine). Romanian Journal of Biology - Zoology 60(2), 125-134.

Matsyura, A.V., Zimaroyeva, A.A., 2016. Osobennosti prostranstvennogo raspredeleniya voronovykh $\mathrm{v}$ usloviyakh transformirovannykh landshaftov Zhytomyrskoy oblasti [Spatial distribution of Corvidae in transformed landscapes of Zhytomyr area]. Vìsn. Dnìpropetr. Unìv. Ser. Bìol. Ekol. 22(1), 53-59 (in Russian).

McDonnell, M.J., Hahs, A.K., 2008. The use of gradient analysis studies in advancing our understanding of the ecology of urbanizing landscapes: Current status and future directions. Landscape Ecol. 23, 1143-1155.

McGowan, K.J., 2001. Demographic and behavioral comparisons of suburban and rural American Crows. In: Marzluff, J.M., Bowman, R., Donelly, R., (eds.) Avian ecology and conservation in an urbanizing world. Kluwer Academic Press, Norwell.

Møller, A.P., Diaz, M., Flensted-Jensen, E., Grim, T., Iba'nezAlamo, J.D., Jokimaki, J.-M., Marko, G., Tryjanowski, P., 2012. High urban population density of birds reflects their timing of urbanization. Oecologia 170, 867-875.

Otto, W., Witt, K., 2002. Verbreitung und Bestand Berliner Brutvőgel. Berl. Ornithol. Ber. 12, Special Issue.

Poluda, A.M., Tsukanova, S.V., 2012. Osobennosti prostranstvenno-vremennogo raspredelenija grachej (Corvus frugilegus), svjazannyh s territoriej Ukrainy [Temporal and spatial distribution of Rook in Ukraine]. Branta 15, 103-120 (in Russian).

Radford, K.G., James, P., 2013. Changes in the value of ecosystem services along a rural-urban gradient: A case study of Greater Manchester, UK. Landscape Urban Plan. 109, 117-127.

Ramalho, C.E., Hobbs, R.J., 2012. Time for a change: Dynamic urban ecology. Trends Ecol. Evol. 27, 179-188.

Ravkin, E.S., Chelintsev, N.G., 1990. Metodicheskie rekomendacii po kompleksnomu marshrutnomu uchetu ptic [Manual on bird transect count]. Nauka, Moscow (in Russian).

Strohbach, M.V., Haase, D., Kabish, N., 2009. Birds and the city: Urban biodiversity, land use, and socioeconomics. Ecol. Soc. 14, 31.

Tratalos, J., Fuller, R.A., Evans, K.L., Davies, R.G., Newson, S.E., Greenwood, J.J.D., Gaston, K.J., 2007. Bird densities are associated with household densities. Glob. Chang. Biol. $13,1685-1695$.

Tryjanowski, P., Sparks, T.H., Kuźniak, S., Czechowski, P., Jerzak, L., 2013. Bird migration advances more strongly in urban environments. PLoS One 8(5), e63482.

Tryjanowski, P., Skórka, P., Sparks, T.H., Biaduń, W., Brauze, T., Hetmański, T., Wysocki, D., 2015a. Urban and rural habitats differ in number and type of bird feeders and in bird species consuming supplementary food. Environ. Sci. Pollut. R. 22(19), 15097-15103.

Tryjanowski, P., Sparks, T.H., Biadun, W., Brauze, T., Hetmański, T., Martyka, R., Wysocki, D., 2015b. Winter bird assemblages in rural and urban environments: A national survey. PLoS ONE 10(6), e0130299.

Надійшла до редколегії 11.09.2016 